\title{
Study on the Problem of Employment of College Students Village Official in China
}

\author{
Xiang Liu, a , Na Fu ${ }^{2,3, b}$ \\ ${ }^{1}$ Tianjin University of Commerce Boustead College, Tianjin, 300384 \\ ${ }^{2}$ Tianjin Agricultural University, Tianjin, 300384 \\ ${ }^{3}$ Shanghai University of Finance and Economics, Shanghai, 200433 \\ âufei_fn@126.com, ${ }^{\mathrm{b}}$ Scarlett_fn@126.com
}

Keywords: college student village official; employment status; brain drain

\begin{abstract}
The college student village official is a major strategic decision made by the Party Central Committee since the 17th National Congress of China. The influence and role of the college student village officials who have served in rural work and the construction of new countryside are obvious to all. They have been widely welcomed and fully affirmed by all walks of life in rural areas, but there are also problems that cannot be ignored. This article analyzes the existing problems in the employment status of college student village officials, and proposes corresponding solutions. It aims to help college student village officials to better play their own value, so as to improve the quality and quantity of college graduates to apply for college student village official, enhance the enthusiasm for village officials and the recruitment rate to reduce the brain drain.
\end{abstract}

\section{Introduction}

The University Student Village Officer Program is an important decision in China and has gone through more than 20 years since 1995. During this period, many changes have taken place. From the initial exploration to the gradual stabilization, it has become A normalized institutional arrangement. In 2005, the General Office of the CPC Central Committee and the General Office of the State Council promulgated the "Opinions on Guiding and Encouraging College Graduates to Facilitate Employment at the Grass-roots Level." "From 2006 onwards, we have planned to select a certain number of college graduates each year to work in rural areas and strive for 3 By the time of five years, the goal of at least one university graduate in each village nationwide has been basically achieved."[1] In 2008, the Central Organization Department promulgated the "Opinions on Selecting Graduates to Work in the Village (Trial)", clearly stating that from 2008 onwards, five consecutive years of employment will be employed, with a total of 100,000 candidates, and will be employed annually 20,000 people. The introduction of this legal system has not only solved the problem of the employment of a part of college graduates, but also attracted and accepted more graduates with the aspiration to work at the grassroots level and serve the grassroots.

In the book "College Student Village Officials" Workbook, Comrade Hu Jintao emphasized that he hopes that the students will go to the grassroots to exercise and develop their talents. This matter has long-term strategic significance. Xi Jinping emphasized at the colloquia village university student representative meeting that "we will try to make college students' village officials go down, stay, do well, and move." Li Yuanchao pointed out that "selecting college students to work in the village is a strategy for training successors." Measures."[2]

\section{Status Quo of College Student Village Official Employment}

By the end of 2014, there were more than 3.5 million university graduates nationwide taking the initiative to apply for university students' village officials, and more than 400,000 undergraduates had been recruited to serve as village officials and serve the grassroots. At the end of 2014, there were 180,960 university graduate students in the country, and the number of university graduates in 
the university accounted for more than one-third of the country's administrative villages.

By comparing the number of male and female sex workers in post-college college students at the end of 2014, there were 102,251 female students in the post of village officials, accounting for $56.5 \%$ of the total number, the number of male village official posts was $43.5 \%$, such as in Figure1. Affected by the policy requirements of hiring university graduates from various localities, many regions have made specific demands for the gender of the hiring village officials. The number of male university graduates employed is relatively small.

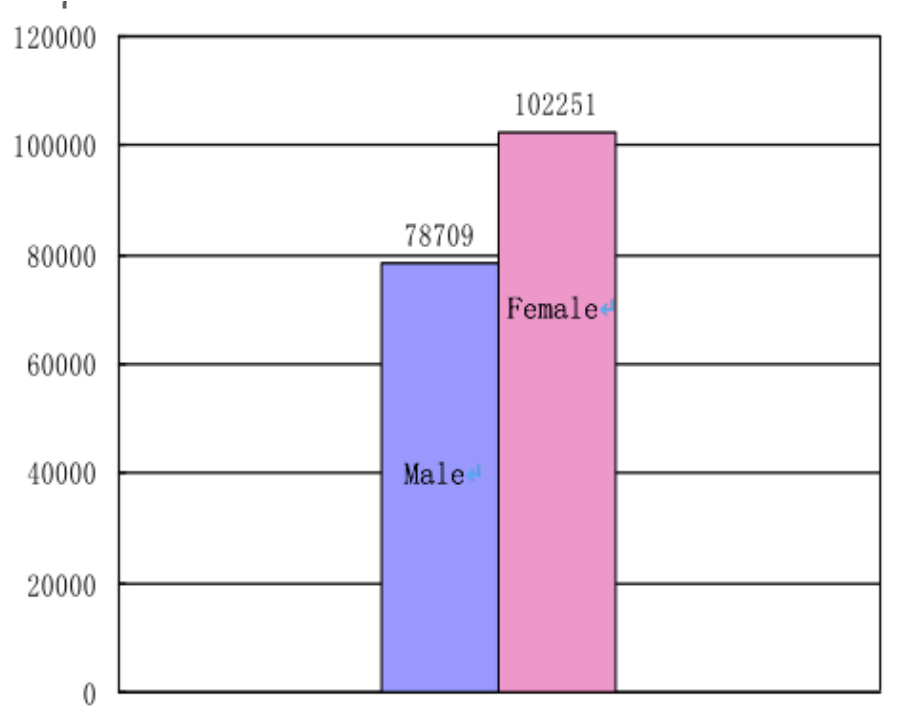

Figure 1 College student village officer gender ratio

Comparison of the Number of Village Officials in Different College Students in China Among them, there are 3806 undergraduate village officials who have obtained master's degree, accounting for $2.1 \%$ of the total number of village officials in 2014 years; $20 \%$ of the village officials who have obtained the junior college degree; and $74.5 \%$ of those who have obtained bachelor degrees in the village. It can be seen from Figure 2 that only a small percentage of university graduates with master's degrees are willing to apply for a village official. In addition, although the number of specialist village officials employed is more than that of doctoral masters, it still occupies less than the number of undergraduate village officials.

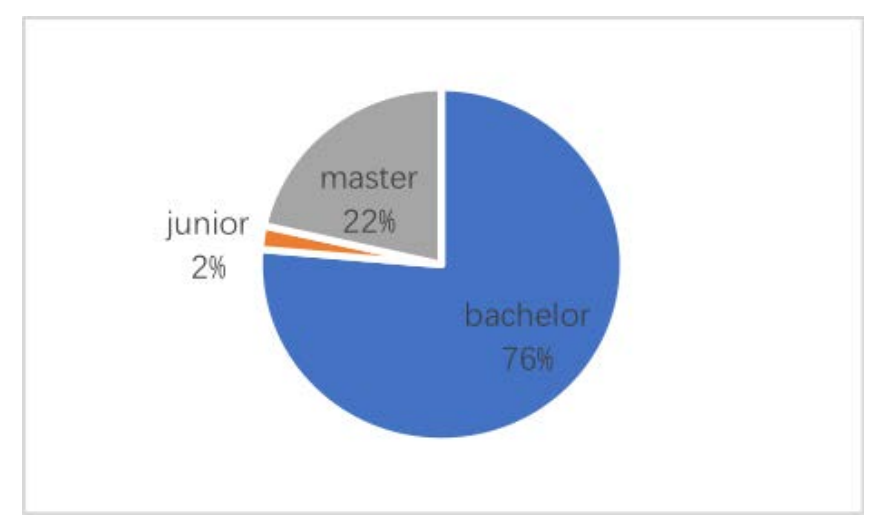

Figure 2 The distribution of college graduates' education

Among the 180,000 college graduate students, there are 9,682 village officials whose political outlook is the masses, and $67.9 \%$ of the village officials who are members of the party in 2014 years. It can be seen from Figure 3 that half of the university officials in the village government officials account for half of the total, while the number of village officials is relatively weak. 


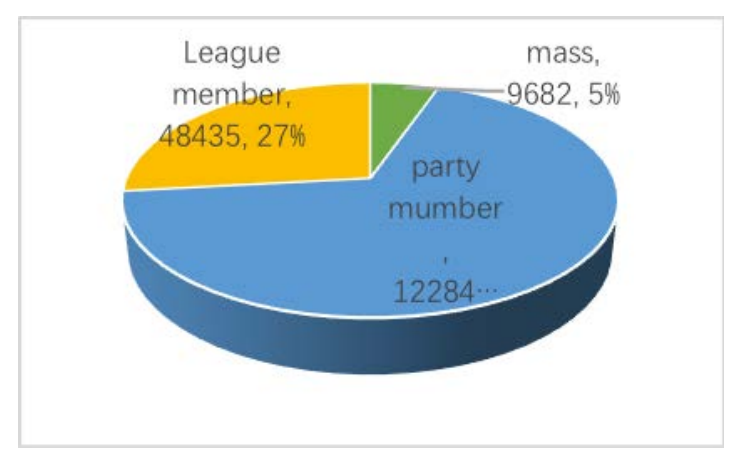

Figure 3 The political outlook of university students' village officials

In addition to the difference in the number of university graduates from undergraduates due to differences in gender, academic qualifications, political outlook, and majors, the colleges and universities that the college graduated from will also affect the college students' choice of applying for the village officials themselves. By the end of 2014, the majority of employed university graduates from universities were graduates from the Ministry of Education and directly affiliated institutions of the central government; a few graduated from local institutions; in addition, only 7\% The college university graduates graduated from private colleges and universities and $1 \%$ graduated from other colleges and universities. It can be see that most of the grass-roots units prefer college students who are college graduates to higher-graduate colleges.

\section{Problems and Influences of College Graduates' Job-hunting Employment}

There are at least the following five situations in which graduate students apply for village officials:

First, listen to the arrangements of the parents. The family wants to enter the exam so they can apply for the exam.

Second, it is difficult to find a job and choose one way out for himself. So he chose to apply for a college student village official.

Thirdly, in some areas, after the college graduates are admitted to the village, although the salary is not high, full-time college graduates can return the university tuition fees. This is also a very attractive policy for newly graduated college students.

Fourth, because the contents of the college student's village official examination are similar to those of the civil service examination, preparation for civil servants in the future is well prepared in advance;

Fifth, we are bent on serving the villagers and contributing to the countryside. We hope to get exercise in the grassroots, improve our own capabilities, and realize our own values and ideals.

The motivation for college students to apply for village officials is so diverse, which shows that the concept of ideology of serving university grassroots college students is not the same. At the same time, this also reflects the mentality of college students applying for village officials, and some college students have the mentality that it is irrelevant whether they are admitted to the exams, or that they will not regard the work of the village officials as a foundation for other businesses in the future, or regard the work of the village officials as a Visiting rural areas to visit the countryside or mobilize the tuition fees of university and village officials from the country or the localities, they did not truly feel like the grassroots work and living environment. Their original motive for choosing a village official was so impure that such a situation would have to be deeply worrying. In China's land, which has a lot of people, there is of course no shortage of young people willing to join the grassroots voluntarily, serve the grassroots, and contribute to the countryside. Among them are children from the countryside and students from the city. The mentality of this group of college students is positive. Their goals and professional career are very clear. They are to work diligently and steadily in their hometowns or in the rural areas where they work. They want to get exercise at work and they also hope to have a great deal of experience. The realization of individual life values and dedication on rural land. Some of them have already become university students. However, 
because the living conditions in rural areas are far different than what they expected or they are not satisfied with the various aspects of the rural environment, and they are afraid of hardship, they cannot help but regret that they have slacked off their work. This in turn affected their own development in the countryside.

Compared with the cities where many undergraduates have lived, the living environment in rural areas is inconvenient. For example, rural transport is not well-developed, stores are not fully prepared, geographical locations are remote, living conditions are not good, signals are weak, and speeches are not understood. Wait. Many university student village officials expressed dissatisfaction with the conditional treatment in rural areas when they were interviewed. Some of the rural environments cannot be changed. For example, the villagers' villagers should speak. Only the university student villagers themselves work hard and do more homework in local speeches. The work of university students' village officials is to enhance rural development and development and benefit farmers. However, if rural areas cannot give them a safe environment, it may make it difficult for them to fully develop their talents.

In addition to rural living environment issues, most rural cadres are influenced by past thoughts and previous developments of village officials. They believe that college students only exercise at the grassroots level and do not necessarily stay long, so the attitude and enthusiasm for arranging work for university students in the village officials is not Gao, some cadres even feel that it is too cumbersome to discuss work with university students. They think that they have no experience at the grassroots level. In addition to the textbook knowledge of the school, practical work requires pointing everywhere. This kind of work environment not only affects the enthusiasm of university students' village officials, but also fails to make full use of this effective resource for university students and causes unnecessary waste of talent.

Village students who were born in rural areas returned to their rural areas where they were able to quickly adapt to the conditions and environment of all aspects of the countryside. However, for university students who have been living in cities or other provinces, let them work at the grassroots level in rural areas. A great deal of exercise and challenge, the rural living conditions are not high, which affects the enthusiasm and initiative of some college students to apply for village officials. For example, due to the constraints of economic conditions in the village, rural living conditions are poor and transportation is not convenient. Many college students are afraid of hardship and are not willing to work in rural areas. Or non-local college students are affected by local speeches. They know that they do not understand dialects, and they set barriers for themselves when they choose to apply for examination. Languages are not directly considered in places where communication is not possible, thus reducing one's chances of choice. Wait.

\section{Countermeasures to Solve Problems of College Student Village Official Employment}

When students apply for village officials, they should not only correct their own mentality, but also make accurate positioning on their own careers. This requires that college students at least make the following points:

First, college students should not follow the crowd when applying for village officials. They must not be allowed to apply for examinations. They should also follow the blind blindly in order to avoid wasting their valuable time;

Second, as a college student, he should have his own opinions and ideas, and he should not only try to test the mentality of his family because of his persecution or expectation. This is not only a waste of part of the country's human resources, but also an irresponsible manifestation of his own.

Thirdly, students who volunteered to apply for university students' village officials must use more time and experience than ordinary people to spend time and experience on the grass-roots building industry. All aspects of ability and skill.

The college student village official shall serve in the countryside. The village cadres should not be biased toward the village officials. Instead, they should actively help the college students to familiarize themselves with the local environment and adapt to the local environment. After all, there are still many village officials who devote their lives to the grass roots. In addition, in order to 
maintain or enhance the enthusiasm of college students, village leaders should try their best to solve some problems that can be solved for them, such as solving village officials' problems of residence and helping village officials understand the village's native culture. Of course, grass-roots village officials should give village officials a good example of positive and diligent work. They should also help each other with college students and village officials to jointly contribute to the development of the rural community.

These requirements for the application of local government policies for college students' village officials have, to a great extent, restricted the registration of many college students. This has not only resulted in the loss of talents, but has also reduced the enthusiasm of college students to apply for village officials. In order to attract more college students to work at the grass-roots level and reduce the turnover rate of university graduates, each local government can consider appropriately reducing the requirements for college graduates to apply for an examination, such as canceling the restrictions on household registration, so that college students have more choice opportunities; and appropriate relaxation of hiring Requires the recruitment of non-graduates or non-members who are interested in rural development.

In some areas, the requirements for hiring college students from village officials are clearly listed in Table 1:

Table 1 Requirements for Hiring College Students in Some Areas

\begin{tabular}{|c|c|}
\hline No & Apply for the requirements of university students \\
\hline 1 & $\begin{array}{c}\text { Only students in this city can apply for the exam. Students who are not registered in the local } \\
\text { household register are not allowed to apply for the exam. Otherwise, they are invalid. }\end{array}$ \\
\hline 2 & Some village official posts indicate recruiting students, non-recruit students do not enroll \\
\hline 3 & Identify graduates with qualifications for undergraduate education or above \\
\hline 4 & $\begin{array}{c}\text { The political appearance of college students who are required to apply for study is party members or } \\
\text { members }\end{array}$ \\
\hline 5 & $\begin{array}{c}\text { Some posts have restricted the sex of university students. } \\
\text { These posts explicitly require that only male or female college students be recruited }\end{array}$ \\
\hline
\end{tabular}

Allowing local governments to encourage and guide village officials to work in public institutions or enterprises is mainly to help university students in villages solve problems they have been worrying about, that is, where to go after the expiration of employment. In this way, with the help of local governments, the college student village official can take a good job at the grassroots level to make a contribution to the grass-roots level without having to slacken and relax the current grass-roots work because of concerns about his future exit.

\section{Conclusion}

This thesis discusses and analyzes many problems in the employment of college students. For example, college graduates have different motivations when applying for the village officials, thus affecting their own employment. The living conditions and the humanistic environment in rural areas also affect the interests of college graduates who apply for village officials. Affected by local policies and national policies, some college students want to apply for village officials, but they do not meet the requirements. This article is based on the problems found in the employment of college students in the village officials, and then analyzes the causes of the problem, and finally put forward the corresponding solutions to the idea of the process, hoping to understand the solution to the problem, so as to solve the college students in the village government employment related The problem is to improve the enthusiasm of college students to apply for village officials, and hopes to ensure the quality and quantity of college graduates to apply for the recruitment rate of university students and reduce the loss and outflow of talents.

\section{References}

[1] The General Office of the Central Committee of the Communist Party of China and the General 
Office of the State Council. Opinions on Guiding and Encouraging College Graduates to Facilitate Employment at the Grassroots Level [R]. Central Office. No. 18, 2005.

[2] Wang Zhuojun. Workbook for "Village Officials" of University Students [M]. Suzhou University Press, 2010.7:8-21.

[3] Mann S. Helen F. Siu. Agents and Victims in South China: Accomplices in Rural Revolution [M]. Yale University Press, 1989.

[4] Jeanc. O.I., State and Peasant in Contemporary China [M]. University of California Press, 1989.

[5] Klimenko E. Association of Universities and Colleges of Canada (AUCC)[J]. Gut Pathogens, 2003, 5(48):43.

[6] Chen Xiangyu, Yang Xiaobiao. Study on the career development of university students' village officials[J]. Business Intelligence, 2013(19):103-103. 